\title{
Sprawozdanie z konferencji naukowej pt. Transdyscyplinarne badania nad śląskim dziedzictwem kulturowym. Świadectwa ducha czasów - nekropolie i pochówki Piastów Ślq̨skich", 24 września 2016 r.
}

24 IX 2016 r. na Zamku Piastów Śląskich w Brzegu w ramach 24 Europejskich Dni Dziedzictwa odbyła się ogólnopolska konferencja naukowa „Transdyscyplinarne badania nad śląskim dziedzictwem kulturowym. Świadectwa ducha czasów - nekropolie i pochówki Piastów Śląskich”, zorganizowana przez Muzeum Piastów Śląskich oraz Wydział Prawa i Administracji Uniwersytetu Opolskiego. Wydarzenie to patronatem objął Starosta Powiatu Brzeskiego Maciej Stefański.

Otwarcia konferencji dokonał dyrektor Muzeum Piastów Śląskich, mgr Paweł Kozerski. Pierwszą sekcję, której przewodniczył prof. UWr dr hab. Maciej Trzciński, otworzyła dr Alicja Jagielska-Burduk (Uniwersytet Kazimierza Wielkiego w Bydgoszczy), która skupiła się na prawnych aspektach w promocji dziedzictwa kulturowego (Prawne i ekonomiczne uwarunkowania upowszechniania i promocji dziedzictwa kulturowego). Następnie głos zabrał prof. UO dr hab. Piotr Stec (Uniwersytet Opolski), a jego wystąpienie dotyczyło problemu związanego z własnością dziedzictwa narodowego (Wtasność dóbr kultury: konflikt pomiędzy interesem publicznym a interesem wtaściciela). Sekcję zamknęła prof. dr hab. Hanna Kóčka-Krenz (Uniwersytet im. Adama Mickiewicza w Poznaniu), która opowiedziała o wpływie przedstawicieli dynastii piastowskiej na wprowadzenie chrześcijaństwa w Polsce (Piastowie a wprowadzenie chrześcijaństwa w Polsce).

Po dyskusji i przerwie kawowej przystąpiono do kolejnej sekcji, której tym razem przewodniczyła prof. dr hab. Hanna Kóčka-Krenz. Dr Magdalena Biniaś- 
-Szkopek (UAM i Biblioteka Kórnicka Polskiej Akademii Nauk) skupiła się na konfliktach Piastów w II połowie XII w., przedstawiając zgromadzonym w czyich rękach znajdował się Śląsk w średniowieczu (Dla kogo Ślask? Konflikty Piastów $w 2$ pot. XII w.). Po niej głos zabrał prof. dr hab. Edward Skibiński (UAM), który $\mathrm{z}$ kolei przybliżył obecność Piastów śląskich w kronikach (Piastowie ślascy w kronikach). O mariażach dynastycznych i koligacjach rodzinnych Piastów brzeskich (Polityka matżeńska i powiąania rodzinne Piastów brzeskich) mówił z kolei ostatni prelegent w tej sekcji, mgr Jakub Wojtczak (UAM).

Ostatni panel, któremu przewodniczył prof. UO dr hab. Piotr Stec, otworzył prof. UWr dr hab. Maciej Trzciński (Uniwersytet Wrocławski). Jego wystąpienie dotyczyło kryminalistycznego, sądowego i archeologicznego podejścia do badań zwłok ludzkich (Kryminalistyczne i archeologiczno-sadowe badania zwłok i szczatków ludzkich o znaczeniu historycznym). Następnie głos zabrał prof. dr hab. Marek Figlerowicz (Polska Akademia Nauk), przybliżył słuchaczom czym jest DNA, jak je pozyskiwać i jak przeprowadzać odpowiednie badania (Historia zapisana w DNA). Następnie, o stanie badań nad miejscem spoczynku Piastów śląskich (Pochówki Piastów Ślaskich - stan badań i perspektywy badawcze) opowiedziała mgr Aleksandra Losik-Sidorska (Biblioteka Kórnicka PAN). Obrady tej sekcji, jak i całej konferencji zamknęła dr Luiza Handschuh (PAN), która przedstawiła zgromadzonym wyniki badań nad szczątkami Piastów brzeskich, przybliżając również perspektywy badawcze i plany nad badaniami kolejnych przedstawicieli dynastii piastowskiej (W poszukiwaniu Piastów).

Oficjalnego podsumowania i zamknięcia konferencji dokonał mgr Paweł Kozerski. Każde wystąpienie cieszyło się dużym zainteresowaniem, a rozmowy w kuluarach przerodziły się w dyskusję. Konferencja poświęcona pochówkom Piastów śląskich pokazała, jak dużym zainteresowaniem cieszy się ta tematyka w obecnych czasach i daje nadzieje na zorganizowanie kolejnego takiego typu wydarzenia.

Mgr Jakub Wojtczak,

Instytut Historii

Wydział Historyczny

Uniwersytet im. Adama Mickiewicza

ul. Umultowska 89d, 61-614 Poznań

kub.wojtczak@gmail.com 